\title{
Insight into Market Supply and Demand of Private Forests in Croatia
}

\author{
Karlo Beljan ${ }^{1, *}$, Ana Bašić2 , Matija Bakarićín , Jiří Dvořák ${ }^{4}$
}

(1) University of Zagreb, Faculty of Forestry and Wood Technology, Institute of Forest Inventory and Management, Svetošimunska 23, HR-10000 Zagreb, Croatia; (2) Višića ulica 2, 21250 Šestanovac, Croatia; (3) University of Zagreb, Faculty of Forestry and Wood Technology, Institute of Forest Engeneering, Svetošimunska 23, HR-10000 Zagreb, Croatia; (4) Czech University of Life Sciences Prague Faculty of Forestry and Wood Sciences Kamycka 1176, 16521 Prague 6 - Suchdol, Czech Republic

* Correspondence: e-mail: kbeljan@sumfak.unizg.hr
Citation: Beljan K, Bašić A, Bakarić $M$, Dvořák J, 2021. Insight into Market Supply and Demand of Private Forests in Croatia. South-east Eur for 12(2): 149-155. https://doi.org/10.15177/ seefor.21-16.

Received: 8 Oct 2021; Revised: 28 Nov 2021; Accepted: 28 Nov 2021; Published online: 17 Dec 2021

\begin{abstract}
Due to their modest $23 \%$ share, private forests in Croatia are a resource that is perceived as less important than state-owned forests. One of the basic characteristics of private forests is fragmentation, which is also the biggest obstacle to a successful and, economically speaking, sustainable management of private forests. The cases in which a private forest with its area and integrity can generate a sustainable economic income to its owner are not common. However, from an economic point of view, private forests still have one advantage. Unlike state-owned forests, private forests can be the subject of investment and change hands. Based on this, this paper investigates the supply of private forests on the free market. For private forests that were publicly put for sale in the period from 2010 to 2020, their spatial-temporal distribution and supply dynamics and trends (price and quantity) were analyzed. The data were collected from the leading real estate advertising platform in Croatia (Njuškalo.hr), and a total of 866 advertisements were analyzed, relating exclusively to the sale of raw wood material along with the accompanying forest land. On the other hand, in order to assess the demand, data were collected on the number of potential buyers who viewed the advertisements (period 2020-2021). In the observed ten-year period, a total of $1,890.63$ ha of private forests with a total asking value of $€ 32.14$ million were offered on the market. The share of advertisements advertised through real estate agencies is $42.1 \%$. The average total annual supply is 170 ha and has a growing trend (in the advertisements in the coastal part of Croatia, the average area is 1.3 ha, while the average area in the continental part is $3 \mathrm{ha}$ ). The prices are not constant but rising. According to compound interest, the price increase in the coastal area is $1.57 \%$ and $7.49 \%$ in the continental area. From the relationship between supply and demand or, more precisely, the relationship between price and the quantity, it was concluded that the market is not well developed and that the price is not affected by the supply/demand quantity of private forests. Furthermore, it was concluded that this market is developing in the direction of a typical real estate market in Croatia due to the fact that forest management and wood processing characteristics of forests do not define the price, but that the price is largely determined by a market with greater financial importance (the market in real estate near the Adriatic coast).
\end{abstract}

Keywords: asking price; supply; demand; Njuškalo.hr; rural development

\section{INTRODUCTION}

The quantity of forests that can potentially be found on the free market is conditioned by two elements. These are the share of private forests and the national forestry strategy of a state. Privately owned forests can themselves be found on the market. At level of the European Union (EU), the share of private forests varies greatly from country to country, ranging from 0.1 to $93 \%$ (Živojinović et al. 2015). As the main representatives of a small share of private forests, we can single out Turkey with $0.1 \%$ and Macedonia with $10 \%$, a medium share in Estonia, Ireland and Serbia with $47 \%$, Germany and Latvia with $48 \%$, Hungary with $50 \%$ and Belgium with 52\%. Austria, Sweden, Norway, Spain and Portugal have a large share of privately-owned forests (above $80 \%$ ). The facts mentioned above point to the connection between the share of private forest ownership of an individual country and the country's economic development. We could say that economically more developed countries have larger shares of private forests and that the forestry's capital mobility is certainly higher than in less-developed countries. 
The national forestry strategy can fully determine the perspective of forests in the context of their presence on the free market. Privately owned forests may be bought and sold, but cases in which the state sells its forests are not common. The Republic of Croatia is an example where forest selling is not possible, which is also legally regulated, except in certain cases of disposition (OG, 145/20). However, in other countries, e.g. in New Zealand, Australia and South Africa, there are cases of forest privatization (Cubbage et al. 2020) and cases of successful forest restitution (Nichiforel et al. 2020), which contribute to a larger presence of forests on the free market. Also, the forest restitution is a present and still ongoing process in Croatia (Krajter et al. 2015).

However, in Europe there is a range of different possibilities/obstacles when the private forest is changing the owner as a result of a purchase (Nichiforel et al. 2020). In some cases, the owner can freely decide to whom to sell (without or with some minor obstacles depending on the country's legislation), but in the majority of the countries the authority needs to be informed by the seller. The authority (i.e. Ministry) decides on pre-emption right which goes to the neighbour, municipality or state favour.

Private forests in Croatia are one category of property that can potentially be found on the market. From the point of view that all economically valuable private forests in Croatia can be the subject of purchase, Beljan et al. (2020) explored their investment potential. Furthermore, Beljan et al. (2021) explored their potential as an independent source of timber for the wood-processing industry. In both cases, it had been assumed that all privately-owned forests could be found on the market; however, this is not entirely correct. In other words, only those forests whose owners are interested in selling can be the subject of buying and selling, i.e. in order to adequately investigate their supply, it is necessary to take into account only those cases in which their legitimate owners have expressed their willingness to sell.

Private forests in many cases are obstructed for active forest management and for being sold on the free market. There are two reasons for that: unsolved property rights (Krajter et al. 2015) and their small size. Unsolved property rights are precisely the reason why it is realistic to expect that not all private forests can be the subject of buying and selling, which leads to the assumption that even if the owner is interested in selling, it is not legally possible to do so (the transfer of ownership). Furthermore, it is evident from the literature review that the average sizes of forest parcels are about 0.34 ha, while forest estates on average amount to 1.28 ha (Berta et al. 2017). The small surface area calls into question the economic justification of the purchase because sustainable income and sustainable forest management are not possible in most cases.

Given that information on legal property relations in terms of private plots is not publicly available, the way to evaluate the domestic private forest market is to focus on all private forests that are publicly advertised for sale (Bašić 2021). The private forest market is, figuratively speaking, a 'place' where bidders offer their forests for sale for a certain price and where buyers can buy them. One of the basic insights into market functioning is the relationship between supply and demand, which shows that in the case of higher supply, prices fall and vice versa (Klemperer, 1996). However, there are also cases of the private forest market where this relationship does not necessarily have to be inversely proportional (Bašić, 2021). Knowing the market is important for understanding the relationship between private and state forests, the relationship between supply and demand, and for recording the amount of financial capital present. Furthermore, knowledge about the market, and above all about the supply, is an indicator of past price and quantity trends on the basis of which it is possible to make predictions of market movements.

In this paper we focused on the domestic market in private forests publicly advertised for sale. The primary goal was to gain initial insights into their characteristics, quantity and prices in the last decade through spatial-temporal analysis. The secondary goal was to describe trends in the asking prices that can serve as a basis for further research and for forecasting future market trends.

\section{MATERIALS AND METHODS}

\section{Materials}

About $49 \%$ of Croatia's land area is covered by forests (including bare forest land that has the potential to become a forest in the future), whereas $24 \%$ of that area is comprised of privately owned forests (Teslak et al. 2018). Private forests (551,922 ha) are characterized by the average length of forest roads of $13.9 \mathrm{~m} \cdot \mathrm{ha}^{-1}$ and $36.3 \mathrm{~m} \cdot \mathrm{ha}^{-1}$ of skid roads and by the growing stock which equals $156 \mathrm{~m}^{3} \cdot \mathrm{ha}^{-1}$. Broadleaved tree species are dominant (common beech $20.9 \%$, sessile oak 13.3\%, European hornbeam 10.3\%) (Čavlović 2010, Teslak et al. 2018). About one quarter is damaged mostly by negative insect impacts and forests are characterized by poor natural regeneration (Čavlović 2010).

The data sample in this research is predefined by several conditions. The first is the spatial frame which is bounded by Croatia's administrative borders and by the area of private forests respectively. Furthermore, we have focused just on those private forests which are listed on the Croatian free market (which are advertised for sale). According to this, their quantity is taken as market supply.

Characteristics of private forests with regard to the distribution of surface categories and the number of their owners are shown in Table 1. The assumption is that each of the presented forest categories (Table 1) can be subject of buying and selling, or that through advertising for sale they can be found on the free market and thus represent the supply. However, in order to achieve the goal of this research, the material will present only those private forests that have been publicly advertised for sale.

The data source was Njuškalo.hr - the largest advertising platform at the national level, from which data on the location, asking price, forest surface area and advertising method (privately or through real estate agencies) were collected for the period from 2010 to 2020. Only the ads offering a forest with the associated forest land were considered. Furthermore, advertisements that had building land or farmland along with the forest were not taken into account.

\section{Methods}

The secondary database (Njuškalo.hr) was the basis for market analysis. We prompted Njuškalo.hr web page 
Table 1. The structure of private forests with regard to property size.

\begin{tabular}{ccccc}
\hline $\begin{array}{c}\text { Property size } \\
\text { (ha) }\end{array}$ & $\begin{array}{c}\text { Surface area } \\
\text { (ha) }\end{array}$ & $\begin{array}{c}\text { The number } \\
\text { of owners }\end{array}$ & $\begin{array}{c}\text { Share in the total area } \\
\text { (\%) }\end{array}$ & $\begin{array}{c}\text { Share in the total number of owners } \\
\text { (\%) }\end{array}$ \\
\hline$<1$ & $99,948.37$ & 365,301 & 42.40 & 87.20 \\
$1.01-5$ & $84,525.66$ & 48,553 & 35,86 & 11.59 \\
$5.01-10$ & $17,320.87$ & 4,300 & 7.35 & 1.02 \\
$10.01-30$ & $7,654.85$ & 710 & 3.25 & 0.17 \\
$30.01-100$ & $1,535.26$ & 24 & 0.65 & 0.01 \\
$>100$ & $23,722.14$ & 27 & 10.49 & 0.01 \\
$\Sigma$ & $234,707.15$ & 418,915 & 100.00 & 100.00 \\
\hline
\end{tabular}

administrators to list data from their database according to the specific queries which are relevant for this research. Database contains 866 advertisements; however, a part of it refers to the same private forests which have been advertised several times. A representative database, i.e. without repetitive ads, contains 751 advertisements.

In order to analyze the time dynamics through descriptive statistics, the data were categorized by the years when the advertisements were published and according to whether they belong to the continental or coastal part of Croatia. Thus, for the period from 2010 to 2020, the data on the number of advertisements, total area, average area, the largest advertised forest, the smallest advertised forest, average asking prices, minimum price, maximum price and the share of sales through agencies were obtained.

For the purposes of spatial analysis, the advertisements were consolidated by residential areas using QGIS 3.10. The consolidation provided data for a total of 466 residential areas in which all private forests in question are located. Furthermore, the data were spatially displayed and the corresponding variables of private forests were visualized using heat maps (graphic representations of data contained in a matrix presented in shades of red).

In addition to secondary data, primary data were collected in order to assess the market demand for private forests. In the period from April 1, 2020 to March 1, 2021, at the beginning of each month, all active ads were checked and the number of potential buyers' views was recorded.

\section{RESULTS}

In the observed period, a total of $1,890.63$ ha of private forests (Table 2) with a total asking value of $€ 32.14$ million were offered on the market. The share of advertisements advertised for sale through agencies was $42.1 \%$. The minimum price per square meter was $0.09 € \cdot \mathrm{m}^{-2}$ for a plot of 31,000 $\mathrm{m}^{2}$ in Donji Andrijevci (Brod-Posavina County) in 2019. At a maximum price of $130.07 € \cdot \mathrm{m}^{-2}$, a plot of $12,058 \mathrm{~m}^{2}$ in Rovinj (Istria County) was offered in 2020.

Table 2 shows the area categories of private forests that were offered on the market. It is evident that private forests which by their surface area belong to the smallest groups (up to 1 ha or 5 ha) represent the biggest part of the supply on the market. The average asking price is generally lower for those forests that are larger by the surface area. It could be said that the price per square meter, or the total asking price, decreases with the increasing size of the private forest. On average, at the level of the whole of Croatia, the average asking price was $3.90 € \cdot \mathrm{m}^{-2}$.

The number of private forests in supply, i.e. the number of forest properties, varied from 34 (2010) to 136 (2020) (Figure 1a). During 2012, a significant increase in supply was recorded. It is important to note that this coincided with the time of the greatest interest of the wood industry, which in the absence of raw materials from state-owned forests turned to the private ones. Thus, the private forest market reacted and the supply and increased accordingly. In 2013, after a sharp decline in the demand of the wood industry for raw wood materials from

Table 2. Categories of private forest size offered on the market with the corresponding price (period 2010-2020).

\begin{tabular}{cccc}
\hline $\begin{array}{c}\text { Property size } \\
\text { (ha) }\end{array}$ & $\begin{array}{c}\text { Supply surface area } \\
\text { (ha) }\end{array}$ & $\begin{array}{c}\text { Share of the forests put up for sale } \\
(\%)\end{array}$ & $\begin{array}{c}\text { Average asking price } \\
\left(€ \cdot \mathrm{ha}^{-1}\right)\end{array}$ \\
\hline$<1$ & 214.28 & 11.33 & 4.97 \\
$1.01-5$ & 603.53 & 31.92 & 2.66 \\
$5.01-10$ & 165.78 & 8.87 & 1.61 \\
$10.01-30$ & 236.60 & 12.51 & 7.69 \\
$30.01-100$ & 145.41 & 27.77 & 1.16 \\
$>100$ & 525.00 & 100.00 & 0.57 \\
$\Sigma$ & $1,890.63$ & & 3.90 \\
\hline
\end{tabular}


private forests, there was a significant decrease in supply, which was increasing slowly since then until the end of the observed period. The number of advertisements in supply in the continental area after 2012 varied around 40, while the supply in the coastal area was significantly lower until 2019, when it increased significantly, and in 2020 the supply in the coastal area was higher than in the continental area.

Also, the supply surface area varied both in the coastal and in the continental areas (Figure 1b). One of the main causes of this unevenness of supply, especially in the continental part of Croatia, is restitution dynamics defined by Croatian law (OG, 92/96). Due to the fact that restitution dynamics and the size of the supply on the market coincide, it is considered that a significant part of the original owners decided to sell, which had an impact on the market (these are forest areas that are often larger than $100 \mathrm{ha}$ ).

The average total annual supply was 170 ha, while the average unit area in the advertisements in the coastal part was $1.3 \mathrm{ha}$, and 3 ha in the continental part. It is obvious that throughout the observed period the surface area share of forests was significantly smaller in the coastal area (Figure 1b). When comparing the supply surface area with the number of advertisements (Figure 1a), the continental and coastal areas were even more divergent.

a)

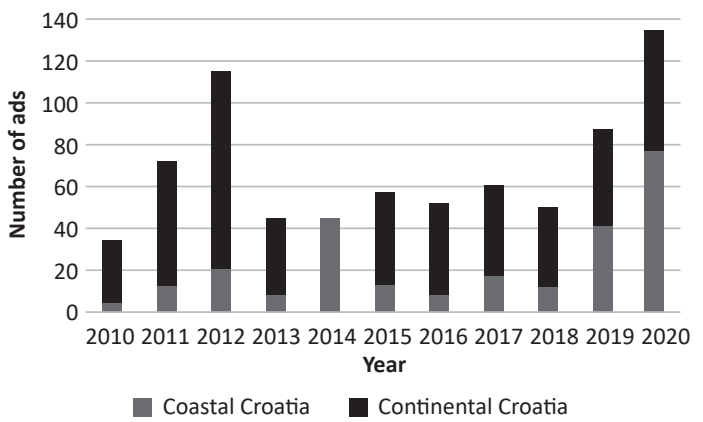

The asking price time dynamics (Figure 2 ) shows significant differences between the prices in continental and coastal Croatia. The price in continental Croatia was almost constant, while in coastal Croatia there was a growing trend in average price. As shown by compound interest, the price increase in the coastal area was $1.57 \%$, and in the continental part $7.49 \%$. If at the level of an individual year (2010-2020) the asking price (Figure 2) is compared with the number of advertisements (Figure 1a) and the total and average surface area in the advertisements (Figure 1b), we can see the non-existence of the interaction between basic market principles. Although the supply of forests in the continental part of Croatia varied (total and average surface area and the number of advertisements (Figure 1)), the price remained almost the same (Figure 2). Also, the same applied to the comparison in the coastal part of Croatia.

The spatial analysis (Figure 3) shows the areas where the supply of private forests was most significant. If we take into account all the elements (Figure $3 \mathrm{a}-\mathrm{d}$ ), it is clear that the area of Istria and Kvarner is somewhat peculiar. Although the central Croatian area, especially northwest of the city of Zagreb (Hrvatsko Zagorje region), is the zone of the largest supply in terms of surface area (Figure 3a), while Istria and Kvarner are in the lead in all the other elements. Namely, in

Figure 1. Time dynamics of the basic supply's characteristics. (a) The quantity of private forests advertised for sale and (b) belonging summarized and average surface.

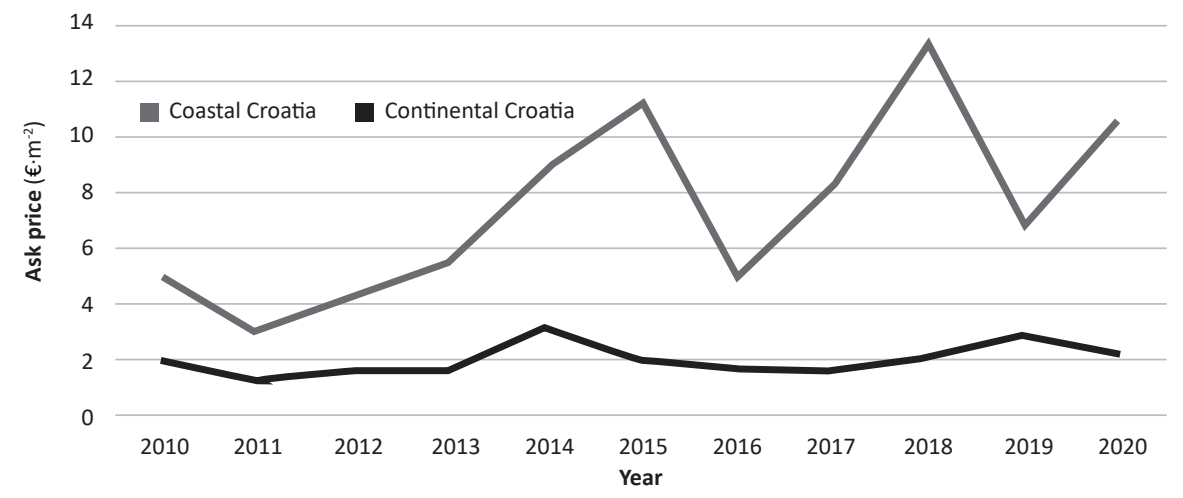

Figure 2. Time dynamics of the asking price.

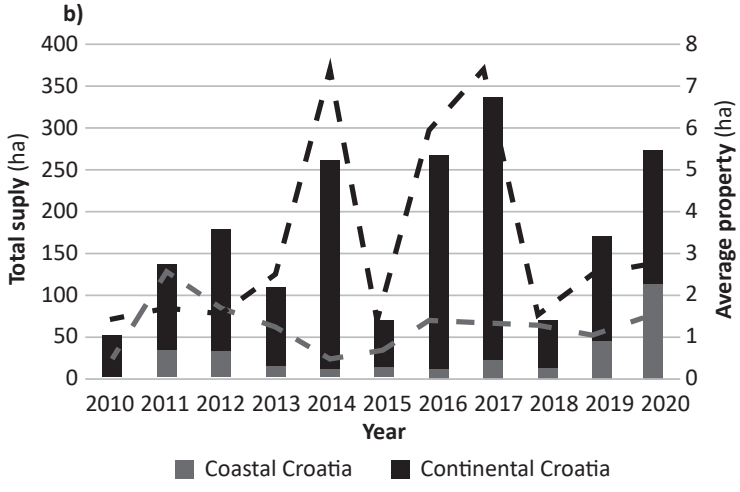




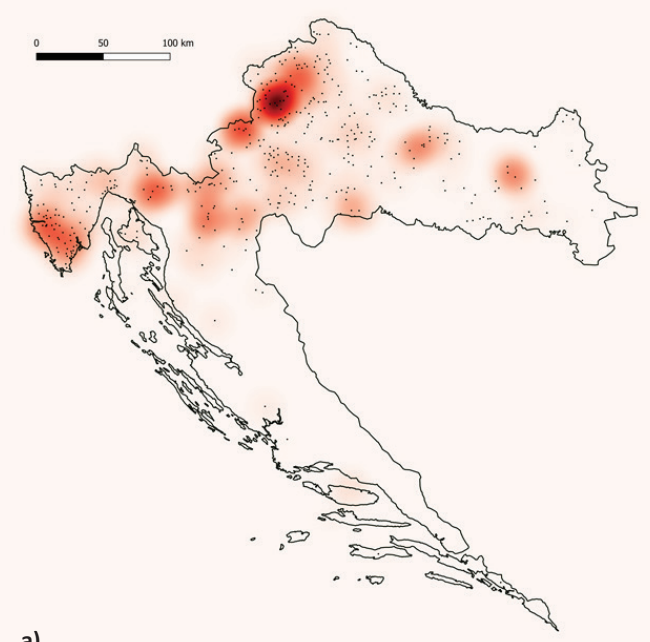

a)

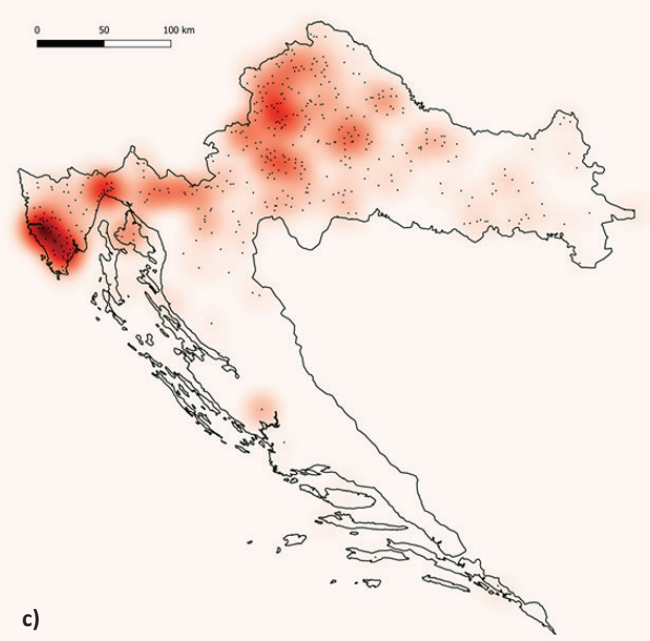

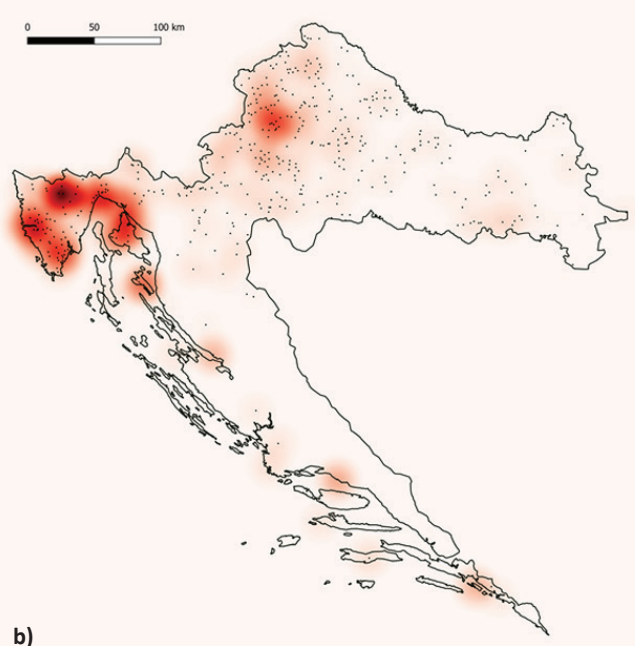

b)

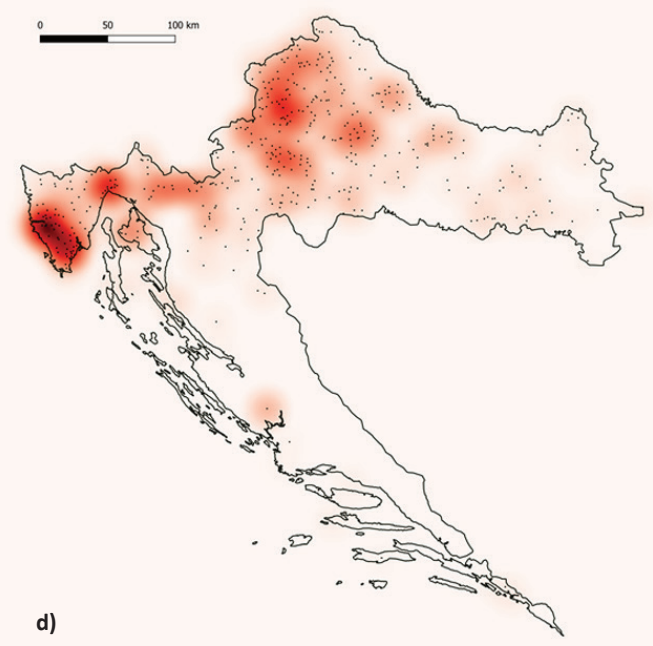

Figure 3. The spatial distribution of private forest supply (2010-2020). (a) total surface area, (b) average price, (c) the number of advertisements, (d) the share of sales through real estate agencies.

the last decade, the highest average asking prices and the total number of advertisements were emphasized precisely in that area. In order to determine forest owner sellers' general approach toward the method of finding a buyer, the share of advertising through real estate agencies was analyzed (Figure $3 d)$. This segment is also spatially related to Istria and Kvarner where private advertising, not through real estate agencies, is very rare (just $9 \%$ of cases).

\section{DISCUSSION}

Previous research on private forests in Croatia provides an overview of the characteristics of the forests themselves and their owners, and their results, e.g. the size of private forests, vary significantly. It is evident from the literature review that the average sizes of forest parcels were about 0.34 ha, while forest estates on average amounted to 1.28 ha (Berta et al. 2017). Our research showed that the average forest property surface area in the advertisements was 2.5 ha, while the median was 0.9 ha.

In this paper, in addition to an overview of the characteristics of private forests, unlike other works so far, an analysis of their market is presented. The data were collected from Njuškalo.hr, which is the leading advertising platform in Croatia but covers only a part of the forests put for sale. Although this online advertising platform is very popular and frequently used in Croatia, it should be considered that some 
of the estates offered for sale are advertised exclusively via other platforms or by personal advertising. Regarding that, the presented results should be taken with a certain level of uncertainty.

Also, the data we presented refer only to the asking price, but it is not known whether the prices were reduced during the sale itself. One of the possible sources of data for obtaining information on the realized purchase price are the Annual bulletins of the Institute of Economics Zagreb (Vizek et al. 2021), which, among other things, provide the overview of the forest land market. However, it is not certain whether the mentioned data would correspond to the real situation on the market (the situation on the forest site). The fact is that so far it has not been defined what determines the purchase price of private forests and how to collect relevant data on the price agreed upon between the seller and the buyer. However, if we assume that the purchased price is lower than the advertised one, this would be correct, but the difference between those two remains unknown.

On the other side of supply stands demand, which describes the number of products that customers are willing to buy at a certain price. Although a significant number of purchase agreements were not available, estimates were used to describe the demand. Figure $4 a$ and Figure $4 b$ show the relationship between the asking price and the number of views by potential buyers (Njuškalo.hr, April 2020-March 2021). Although shown separately, advertisements in the coastal area and in the continental area very clearly indicate potential buyers' greater interest for on average lowerpriced private forests (Figure 4a). However, when looking at demand with respect to the total asking price (Figure $4 \mathrm{~b}$ ), it is not possible to define the link between price and demand. Although this is not usual in terms of supply and demand, we can say that the private forest market is characterized by atypical market laws.

\section{CONCLUSIONS}

The supply of private forests on the free market in the last ten years has been marked by changes in all researched variables. Prices have risen (both in the coastal and the continental area, but in the coastal area the rise was multiple), the total and average surface area varied from year to year, and sellers are increasingly abandoning the classic market approach and they are turning to real estate agencies.

From the relationship between supply and demand, more precisely, the relationship between the asking price and the quantity on offer, the absence of basic market laws was observed. The conclusion is that the market is not well developed and that the price is not affected by the ratio of supply or demand, but by some of the hitherto unexplored characteristics of these forests.

The spatial analysis showed which areas are dominant when it comes to the free market of private forests. Although Istria and Kvarner are marked as hotspots according to several researched elements, we can conclude that the market is developing more in the direction of a typical real estate market. From the forest management and wood-processing aspect, the forests which are traded the most do not represent a significant value in traditional forestry concepts - higher timber stock, higher price. It can be concluded that the monetary value and supply of private forests are most likely determined by the high demand for land near the coast. It is necessary to emphasize that similar supply and demand relations are present along the entire coast, but the lands that are listed as forest land (in cadaster) and advertised for sale, are located in Istria and Kvarner.

\section{Author Contributions}

$K B, A B$, conceived and designed the research, $A B$ carried out the data collection, $A B$ processed the data and performed the analysis, JD and MB supervised the research and helped to draft the manuscript, KB and JD wrote the manuscript. All authors have read and agreed to this version of the manuscript.

\section{Funding}

This research received no external funding.

\section{Acknowledgments}

Authors would like to express acknowledgement to the Njuškalo.hr (a leading advertising platform at Croatia's national level) for providing the valuable input data.

\section{Conflicts of Interest}

The authors declare no conflict of interest. a)

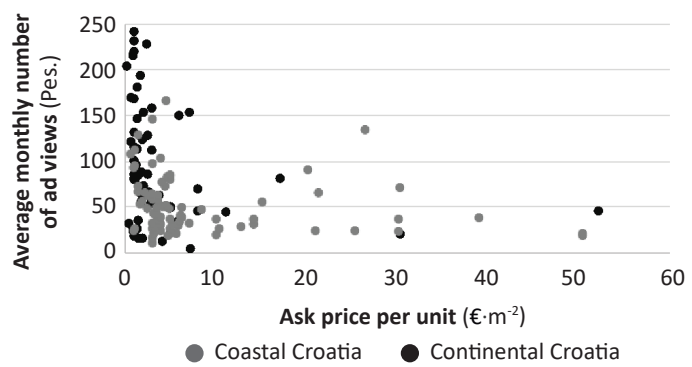

b)

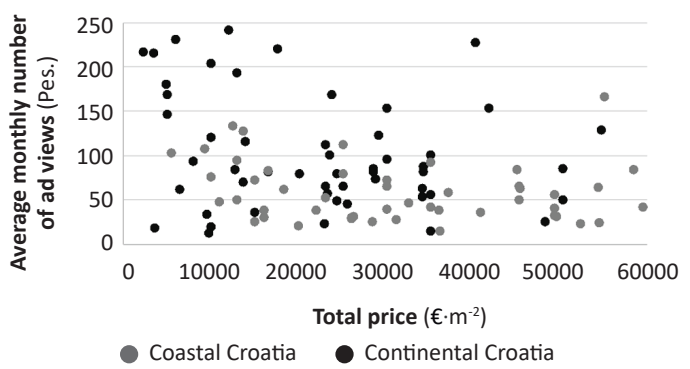

Figure 4. Estimation of market demand for private forests. Comparison between unit (a) and the total asking price (b) to the average number of monthly views made by the potential buyers 


\section{REFERENCES}

Bašić A, 2021. Analysis of the price structure of private forests. Master's thesis, University of Zagreb, Faculty of Forestry and Wood Technology, Zagreb, Croatia, 43 p. Available online: https:// urn.nsk.hr/urn:nbn:hr:108:700890 (1 October 2021). [in Croatian with English summary].

Beljan K, Bašić A, Posavec S, 2021. Timber from private forests as a source for wood-processing industry. In: Jošt M (ed) The Response of the Forest-Based sector to Changes in the Global Economy. WoodEMA, i.a., Koper, Slovenia, pp. 135-140. Available online: https://www.bib.irb.hr/1132924 (1 September 2021).

Beljan K, Čavlović J, Ištvanić J, Dolinar D, Lepoglavec K, 2020. Investment Potential of Private Forests in Croatia. Small-scale For 19: 19-38. https://doi.org/10.1007/s11842-019-09429-1.

Berta A, Kušan V, Križan J, Stojesavljević D, Hatić D, 2017. Estate characteristics of private-owned forests in Croatia according to regions. Šumar List 141(1-2): 57-65. https://doi.org/10.31298/ sl.141.1-2.6. [in Croatian with English summary].

Čavlović J, 2010. The First National Forest Inventory in Republic of Croatia. Ministry of Regional Development and Forestry \& Faculty of Forestry and Wood Technology, Zagreb, Croatia, $256 \mathrm{p}$.

Cubbage F, Kanieski B, Rubilar R, Bussoni A, Olmos VM, Balmelli G, Donagh P Mac, Lord R, Hernández C, Zhang P, Huang J, Korhonen J, Yao R, Hall P, Del La Torre R, Diaz-Balteiro L, Carrero O, Monges E, Thu HTT, Frey G, Howard M, Chavet M, Mochan S, Hoeflich VA, Chudy R, Maass D, Chizmar S, Abt R, 2020. Global timber investments, 2005 to 2017. Forest Policy Econ 112: 102082. https://doi.org/10.1016/j.forpol.2019.102082.

Vizek M, Slijepčević S, Rašić Bakarić I, Stojčić N, 2021. Overview of the real estate market in the Republic of Croatia: 2020. Institute of Economics, Zagreb, Croatia, 199 p. Available online: https:// urn.nsk.hr/urn:nbn:hr:213:945768 (1 September 2021). [in Croatian].

Klemperer WD, 1996. Forest Resource Economics and Finance. McGraw-Hill, New York, USA, 551 p.
Krajter S, Posavec S, Paladinić E, Županić M, Beljan K, Curman M, Ćaleta M, 2015. Forest land ownership change in Croatia. In: Živojinović I, Weiss G, Lidestav G, Feliciano D, Hujala T, Dobšinská Z, Lawrence A, Nybakk E, Quiroga S, Schraml U (eds), Forest Land Ownership Change in Europe. COST Action FP1201 FACESMAP Country Reports, Joint Volume, University of Natural Resources and Life Sciences (BOKU), Vienna, Austria, pp. 1-40.

Nichiforel L, Deuffic P, Thorsen BJ, Weiss G, Hujala T, Keary K, Lawrence A, Avdibegović M, Dobšinská Z, Feliciano D, GórrizMifsud E, Hoogstra-Klein M, Hrib M, Jarský V, Jodłowski K, Lukmine D, Pezdevšek Malovrh Š, Nedeljković J, Nonić D, Krajter Ostoić S, Pukall K, Rondeux J, Samara T, Sarvašová Z, Scriban RE, Šilingienè $R$, Sinko $M$, Stojanovska $M$, Stojanovski $V$, Stoyanov T, Teder M, Vennesland B, Wilhelmsson E, Wilkes-Allemann J, Živojinović I, Bouriaud L, 2020. Two decades of forest-related legislation changes in European countries analysed from a property rights perspective. Forest Policy Econ 115: 102146. https://doi.org/10.1016/i.forpol.2020.102146.

OG, n.d. Forest law . Off. Gaz. 40/05, 82/06, 129/08, 80/10, 124/10, 25/12, 68/12, 148/13, 94/14, 145/2020. [in Croatian]

OG, n.d. The law on compensation for property taken during the yugoslav communist regime (in Croatian). Off. Gaz. 92/1996. [in Croatian]

Teslak K, Žunić M, Beljan K, Čavlović J, 2018. Status and challenges of small-scale private forest management in actual ecological and social circumstances - Croatia case study. Šumar List (142), 459-471. https://doi.org/10.31298/sl.142.9-10.1. [in Croatian with English summary].

Živojinović I, Weiss G, Lidestav G, Feliciano D, Hujala T, Dobšinská Z, Lawrence A, Nybakk E, Quiroga S, Schraml U, 2015. Forest Land Ownership Change in Europe. COST Action FP1201 FACESMAP Country Reports, Joint Volume, University of Natural Resources and Life Sciences (BOKU), Vienna, Austria. 
